\title{
Pengaruh Motivasi Belajar Siswa Terhadap Prestasi Belajar Siswa Melalui Penerapan Strategi Pembelajaran Kooperatif Tipe Teams Games Tournament (TGT)
}

\author{
Dywanti Oktavia Paramitha \\ Program Studi Pendidikan Sejarah FKIP Universitas Lambung Mangkurat \\ Banjarmasin \\ Email:dywantioktaviaaaa@gmail.com
}

\begin{abstract}
Abstrak: Guru sebagai pendidik ataupun pengajar merupakan faktor penentu kesuksesan setiap usaha pendidikan. Ia sebagai suri tauladan bagi siswanya, seorang peserta didik akan memperhatikan kemudian menirukan apa yang dilakukan oleh gurunya. Menurut Arifin (2009:2) "Prestasi merupakan hasil yang dicapai seseorang setelah memperoleh proses untuk mendapatkan perubahan tingkah laku baik kognitif, afektif maupun psikomotorik". Keberhasilan suatu lembaga pendidikan dapat dilihat dari hasil prestasi belajar siswa. Prestasi belajar merupakan tolak ukur yang telah dicapai oleh peserta didik setelah melakukan kegiatan belajar mengajar didalam kelas selama waktu yang telah ditentukan.
\end{abstract}

Kata Kunci: Motivasi Belajar, Strategi Pembelajaran Kooperatif, Model Pembelajaran Teams Games Tournament

\section{PENDAHULUAN}

Perkembangan zaman di dunia pendidikan yang terus berubah dengan signifikan sehingga menyebabkan banyak perubahan pola pikir pendidik, dari pola pikir yang awam dan kaku menjadi lebih modern. Hal tersebut sangat berpengaruh dalam kemajuan pendidikan di Indonesia. Ditinjau dari segi pendidikan, pada hakekatnya pendidikan adalah proses pembudayaan secara terus-menerus dan sistematis yang akan membentuk kepribadian peserta didik menjadi manusia dewasa yang seutuhnya.

Dalam fakta sejarah pendidikan telah membawa banyak perubahan bukan hanya perubahan pada diri individu terdidik akan tetapi juga perubahana bangsa dan Negara.Tujuan pendidikan itu sendiri adalah menciptakan individu yang berkualitas dan berkarakter sehingga memiliki pandangan yang luas ke depan untuk mencapai suatu citacita yang diharapkan dan mampu beradaptasi secara cepat dan tepat di dalam berbagai lingkungan, karena pendidikan mampu memotivasi diri kita untuk lebih baik dalam segala aspek kehidupan. Jika dikaitkan dengan pembelajaran sejarah yang tujuannya untuk melatih kemampuan siswa untuk berfikir historis merupakan upaya untuk 
menjadikan pembelajaran sejarah sebagai media untuk pembentukan keterampilan akademis tingkat tinggi dan pembentukan sikap dan pola perilaku ilmiah. Dalam segi pemahaman sejarah sendiri member petunjuk kepada kita untuk melihat serangkaian perisstiwa masa lalu sebagai system tindakan masa lalu sesuai dengan jiwa zamannya, akan tetapi memiliki sekumpulan nilai edukatif terhadap kehidupan sekrang dan yang akan dating. Mengingat pentingnya proses pembelajaran tersebut, maka selayaknya pembelajaran sejarah untuk melatih kemempuan berfikir historis.

Model pembelajaran akan ikut menentukan keberhasilan tujuan pembelajaran mengingat melalui model pembelajaran inilah guru mampu merancang aktivitas siswa dan menentukan capaian-capaian yang diinginkan dengan menggunakan aktivitas terencana dalam proses belajar.

\section{MOTIVASI BELAJAR}

Motivasi belajar merupakan salah satu dimensi penting bagi pembelajaran guna meningkatkan perolehan belajar. Motivasi belajar ada yang bersumber dari kebutuhan pembelajaran. Faktor utama yang mempengaruhi minat dan motivasi belajar siswa adalah cara mengajar guru, karakter guru, suasan kelas tenang dan nyaman, dan fasilitas belajar yang digunakan.

Di dalam kegiatan belajar mengajar untuk memberi motivasi kepada siswanya dimulai dari diri sendiri, yang mana seorang guru senantiasa memiliki motivasi yang kuat dalam mewujudkan perilaku keguruan-nya. Dengan memotivasi yang kuat, maka guru akan berperilaku lebih baik, sehingga dapat membantu proses perkembangan siswa. Dengan demikian, untuk mengoptimalkan prestasi belajar, maka usaha-usaha yang harus dilakukan seorang guru adalah dengan profesional guru, meningkatkan komunikasi guru dengan peserta didiknya, serta mencari model, metode maupun strategi belajar mengajar yang sesuai dengan materi dan kondisi siswa. Dengan usaha-usaha tersebut diharapkan siswa memiliki tanggapan yang baik terhadap gaya mengajar guru sehingga mereka dapat meningkat-kan prestasi belajarnya.

Siswa akan memiliki motivasi dan kreativitas belajar yang tinggi apabila sudah merasa senang dan nyaman dengan guru kemudian mencintai mata pelajarannya. Karena pada hakekatnya tidak ada siswa yang bodoh atau pintar. Akan tetapi, perbandingan yang sebenarnya ialah siswa pemalas dan rajin. Siswa yang rajin akan dengan sangat mudah untuk mendapatkan prestasi belajar yang tinggi. Banyak hal yang dapat dilakukan oleh guru sebagai upaya untuk meningkatkan motivasi belajar diantaranya : (1)Optimalisasi Penerapan Prinsip Belajar, (2)Optimalisasi unsur dinamis belajar dan pembelajaran, (3)Optimalisasi Unsur Dinamis Belajar dan Pembelajaran, (4)Optimalisasi Pemanfaatan Pengalaman dan Kemampuan,(5) Pengembangan cita-cita aspirasi Belajar. Bila guru berupaya untuk melakuka kelima hal tersebut motivasi belajar siswa akan meningkat. 


\section{STRATEGI PEMBELAJARAN KOOPERATIF}

Strategi Pembelajaran Kooperatif merupakan rangakaian kegiatan pembelajaran, dimana para siswa bekerjasama dalam kelompok-kelompok kecil untuk mempelajari materi dan diberikan penghargaan atas keberhasilan kelompoknya (Slawvin,1995; Cruisckshank, Jenkins, dan Metcalf, 2006).

Menurut Miarso (2004), strategi pembelajaran adalah pendekatan menyeluruh pembelajaran, yang berupa pedoman umum dan kerangka kegiatan untuk mencapai tujuan umum pembelajaran, yang dijabarkan dari pandangan falsafah dan atau teori belajar tertentu. Dari batasan-batasan itu, dapat dipahami bahwa strategi pembelajaran merupakan pola rangkaian perbuatan guru-siswa dalam mewujudkan peristiwa pembelajaran yang efektif untuk mencapai suatu tujuan pembelajaran tertentu. Sebagai suatu pola aktivitas guru-siswa, strategi pembelajaran memuat sejumlah komponen yang membentuk wadah yang disebut pola pembelajaran. Pada dasarnya strategi pembelajaran kooperatif mempunyai dua tujuan, yaitu kebaikan bersama dan kebaikan individu. Tujuan ini mempunyai makna filosofis, yaitu satu untuk semua dan semua untuk satu (Cruickshank, Jenkins, dan Metcalf, 2006). Ada tiga tujuan dari penerapan strategi pembelajaran koperatif, yaitu peningkatan prestasi akademis, penerimaan keragaman, dan pengembangan keterampilan social (Arends, 1998; Alrasydin dan Nasution, 2015; Suprihatiningrum, 2016).

Stahl (2004) mengatakan bahwa, ciri-ciri penting pembelajaran kooperatif adalah adanya tujuan-tujuan pembelajaran khusus yang jelas, seluruh siswa bekerjasama untuk mencapai tujuan pembelajaran, adanya pengarahan yang jelas terhadap tugas-tugas yang harus dilakukan oleh siswa, kelompok yang beragam, siswa memiliki peluang yang sama untuk sukses, ketergantungan yang positif, terjadi tatap muka dan percakapan antar siswa, sikap dan tingkah laku berinteraksi sosial yang positif, tanggung jawab individu, penghargaan dan hadiah untuk tim yang sukses secara akademis.

Hal senada juga, dikemukakan oleh Cooper (2004), yang menyatakan bahwa belajar dengan strategi pembelajaran kooperatif memiliki ciri, saling ketergantungan positif antar anggota kelompok, tanggung jawab secara individu, heterogen, menekankan pada tugas dan kebersamaan, membentuk keterampilan sosial, peran guru sebagai fasilitator dan mengamati terhadap proses belajar siswa, dan tatap muka untuk memecahkan masalah.

Melalui strategi pembelajaran kooperatif dapat juga meningkatkan dan mengembangkan pemikiran yang kritis dan kreatif, meningkatkan harga diri, kesadaran sosial, dan toleransi antar individu yang beragam (Holt, 2004). Disamping itu, pembelajaran kooperatif dapat meningkatkan percaya diri akademik, suka pada kelas dan teman-teman sekelas, menumbuhkan rasa empati dan kerjasama social (Omrod, 2001). 
Strategi pembelajaran kooperatif telah dikembangkan secara intensif melalui berbagai penelitian. Ada tiga strategi pembelajaran kooperatif yang dapat dikembangkan pada hampir semua subjek dan tingkatan yaitu; (1) Students Teams Achievement Division (STAD), (2) Team Games Tournament, dan Jigsaw II.

\section{MODEL PEMBELAJARAN TEAMS GAMES TOURNAMENT (TGT)}

1. Pengertian Model Pembelajaran

Model pembelajaran adalah suatu perencanaan atau suatu pola yang digunakan sebagai pedoman dalam merencanakan pembelajaran di kelas atau pembelajaran dalam tutorial. Model pembelajaran mengacu pada pendekatan pembelajaran yang akan digunakan, termasuk di dalamnya tujuan-tujuan pengajaran, tahap-tahap dalam kegiatan pembelajaran, lingkungan pembelajaran dan pengelolaan kelas (Arends, 1997:7). Begitu juga dengan pendapat Joyce (1992:4) bahwa setiap model mengarahkan kita dalam merancang pembelajaran untuk membantu peserta didik mencapai tujuan pembelajaran.

2. Pengertian Team Games Tournament (TGT)

Model pembelajaran Teams Games Tournament (TGT) adalah salah satu tipe atau model pembelajaran kooperatif yang mudah diterapkan, melibatkan aktivitas seluruh siswa tanpa harus ada perbedaan status, melibatkan peran siswa sebagai tutor sebaya dan mengandung unsur permainan dan reinforcement. Aktivitas belajar dengan permainan yang dirancang dalam pembelajaran kooperatif model Teams Games Tournament (TGT) memungkinkan siswa dapat belajar lebih rileks disamping menumbuhkan tanggung jawab, kejujuran, kerja sama, persaingan sehat dan keterlibatan belajar.

3. Langkah - langkah penerapan Team Games Tournament (TGT)

Secara umum ada 5 komponen utama dalam penerapan model TGT, yaitu:

3.1 Penyajian Kelas (Class Presentations)

Pada awal pembelajaran guru menyampaikan materi dalam penyajian kelas atau sering juga disebut dengan presentasi kelas (class presentations). Guru menyampaikan tujuan pembelajaran, pokok materi dan penjelasan singkat tentang LKS yang dibagikan kepada kelompok. Kegiatan ini biasanya dilakukan dengan pengajaran langsung atau dengan ceramah yang dipimpin oleh guru.

\subsection{Belajar dalam Kelompok (Teams)}

Guru membagi kelas menjadi kelompok-kelompok berdasarkan kriteria kemampuan (prestasi) peserta didik dari ulangan harian sebelumnya, jenis kelamin, etnik dan ras. Kelompok biasanya terdiri dari 5 sampai 6 orang peserta didik.

\subsection{Permainan (Games)}

Game atau permainan terdiri dari pertanyaan-pertanyaan yang relevan dengan materi, dan dirancang untuk menguji pengetahuan yang didapat peserta didik dari 
penyajian kelas dan belajar kelompok. Kebanyakan game atau permainan terdiri dari pertanyaan-pertanyaan sederhana bernomor. Game atau permainan ini dimainkan pada meja turnamen atau lomba oleh 3 orang peserta didik yang mewakili tim atau kelompoknya masing-masing.

3.4 Pertandingan atau Lomba (Tournament)

Turnamen atau lomba adalah struktur belajar, dimana game atau permainan terjadi. Biasanya turnamen atau lomba dilakukan pada akhir minggu atau pada setiap unit setelah guru melakukan presentasi kelas dan kelompok sudah mengerjakan lembar kerja peserta didik (LKPD).

\subsection{Penghargaan Kelompok (Team Recognition)}

Setelah turnamen atau lomba berakhir, guru kemudian mengumumkan kelompok yang menang, masing-masing tim atau kelompok akan mendapat sertifikat atau hadiah apabila rata-rata skor memenuhi kriteria yang telah ditentukan. Tim atau kelompok mendapat julukan "Super Team" jika rata-rata skor 50 atau lebih, "Great Team" apabila rata-rata mencapai 50-40 dan "Good Team" apabila rataratanya 40 kebawah. Hal ini dapat menyenangkan para peserta didik atas prestasi yang telah mereka buat.

\section{PENUTUP}

Motivasi belajar merupakan salah satu dimensi penting bagi pembelajaran guna meningkatkan perolehan belajar. Motivasi belajar ada yang bersumber dari kebutuhan pembelajaran. Siswa akan memiliki motivasi dan kreativitas belajar yang tinggi apabila sudah merasa senang dan nyaman dengan guru kemudian mencintai mata pelajarannya.

Strategi pembelajaran kooperatif dapat juga meningkatkan dan mengembangkan pemikiran yang kritis dan kreatif, meningkatkan harga diri, kesadaran sosial, dan toleransi antar individu yang beragam. Disamping itu, pembelajaran kooperatif dapat meningkatkan percaya diri akademik, suka pada kelas dan teman-teman sekelas, menumbuhkan rasa empati dan kerjasama social dan Strategi pembelajaran kooperatif telah dikembangkan secara intensif melalui berbagai penelitian.

Model pembelajaran Teams Games Tournament (TGT) adalah salah satu tipe atau model pembelajaran kooperatif yang mudah diterapkan, melibatkan aktivitas seluruh siswa tanpa harus ada perbedaan status, melibatkan peran siswa sebagai tutor sebaya dan mengandung unsur permainan dan reinforcement. Aktivitas belajar dengan permainan yang dirancang dalam pembelajaran kooperatif model Teams Games Tournament (TGT) memungkinkan siswa dapat belajar lebih rileks disamping menumbuhkan tanggung jawab, kejujuran, kerja sama, persaingan sehat dan keterlibatan belajar. 


\section{DAFTAR PUSTAKA}

Susanto, H. (2015) Mengadirkan Kelas Kontruktivis dalam Melatih Kemampuan Berpikir Historis Melalui Model Latihan Penelitian.

Susanto,H.(2014). Seputar Pembelajaran Sejarah; Isu, Gagasan Dan Strategi Pembelajaran. Aswaja Pressindo

Susanto.H (2016). Pendidikan Dan Kesadaran Nasionalisme

Abbas, E. W., Ahmad, A. R., Awang, M. M., \& Susanto, H. (2017). Pendidikan Sejarah, Patrotisme \& Karakter Bangsa Malaysia-Indonesia. 107.

Nasution, W. N., \& Ritonga, A. A. (2019). Strategi Pembelajaran Kooperatif Konsep Diri Dan Hasi Belajar Sejarah. Medan: CV.Widya Puspita.

Triumiana, D. A., \& Sumadi. (2016). Hubungan Antara Gaya Mengajar Guru, Motivasi Belajar Siswa Dan Kreativitas Belajar Siswa Dengan Prestasi Belajar Fisika

Aritonang, K. T. (2008). Minat dan Motivasi dalam meningkatkan hasil belajar siswa.

Djalal, F. (2017). Optimalisasi Pembelajaran Melalui Pendekatan.

Manner, T. (2018). Upaya Guru Meingkatkan Motivasi Belajar Siswa

Moh, S. (2009). Motivasi Belajar Yang Bersumer Dari Kebutuhan dan Nilai-Nilai Keagamaan Pembelajar. 